This is an electronic reprint of the original article. This reprint may differ from the original in pagination and typographic detail. Author(s): Vähäsantanen, Katja; Hökkä, Päivi; Paloniemi, Susanna; Herranen, Sanna; Eteläpelto,
Anneli

Title: $\quad$ Professional learning and agency in an identity coaching programme

Year: $\quad 2017$

Version:

Please cite the original version:

Vähäsantanen, K., Hökkä, P., Paloniemi, S., Herranen, S., \& Eteläpelto, A. (2017).

Professional learning and agency in an identity coaching programme. Professional

Development in Education, 43(4), 514-536.

https://doi.org/10.1080/19415257.2016.1231131

All material supplied via JYX is protected by copyright and other intellectual property rights, and duplication or sale of all or part of any of the repository collections is not permitted, except that material may be duplicated by you for your research use or educational purposes in electronic or print form. You must obtain permission for any other use. Electronic or print copies may not be offered, whether for sale or otherwise to anyone who is not an authorised user. 


\section{Professional learning and agency in an identity coaching programme}

Katja Vähäsantanen, Päivi Hökkä, Susanna Paloniemi, Sanna Herranen and Anneli Eteläpelto

Department of Education, University of Jyväskylä, Jyväskylä, Finland

Katja Vähäsantanen, Corresponding author

University of Jyväskylä, Department of Education

P.O. Box 35 (RUU D422)

40014 University of Jyväskylä, Finland

Tel: +358503290678

E-mail: katja.vahasantanen@jyu.fi

Päivi Hökkä

University of Jyväskylä, Department of Education

P.O. Box 35 (RUU D422)

40014 University of Jyväskylä, Finland

Tel: +358408053640

E-mail: paivi.hokka@,jyu.fi

Susanna Paloniemi

University of Jyväskylä, Department of Education

P.O. Box 35 (RUU D422) 
40014 University of Jyväskylä, Finland

Tel: +358408053646

E-mail: susanna.paloniemi@jyu.fi

Sanna Herranen

University of Jyväskylä, Department of Education

P.O. Box 35 (RUU B324)

40014 University of Jyväskylä, Finland

Tel: +358408053639

E-mail: sanna.m.herranen@jyu.fi

Anneli Eteläpelto

University of Jyväskylä, Department of Education

P.O. Box 35 (RUU D437)

40014 University of Jyväskylä, Finland

Tel: +358405755490

E-mail: anneli.etelapelto@jyu.fi

\section{Acknowledgements}

This work was supported by the Academy of Finland under Grant number 288925 [The Role of Emotions in Agentic Learning at Work]. The authors are grateful to the reviewers of the manuscript, to the interviewees, and to Donald Adamson, who polished the language of the paper. We also wish to thank Salme Mahlakaarto, PhD, who was the coach in the identity coaching programme. 


\title{
Professional learning and agency in an identity coaching programme
}

\begin{abstract}
This paper addresses the professional learning that occurred in an identity coaching programme. The arts-based programme aimed to enhance the participants' professional learning, notably through helping them to process their professional identities. Professional learning was seen as resourced by the participants' professional agency, and by the promotion of such agency. Via interviews, we investigated what the participants perceived they had learnt during the programme, and the potential differences in learning outcomes between professional groups from university and hospital contexts. The findings showed that the programme was perceived as a rich learning arena in the domains of the professional self (involving a crafted professional identity), professional relationships (involving increased knowledge of colleagues and becoming an active participant in the work community), and professional competencies (involving socio-emotional knowledge and skills). The professionals (academics and administrative personnel) from a university learnt more during the programme than did the nurses and physicians working in a hospital. The findings suggest that the primary emphasis in professional learning should be on professional identity and agency within the social relationships that exist in training and work settings. The paper also presents our theoretical considerations regarding the connection between professional agency and learning.
\end{abstract}

Keywords: professional learning; professional identity; professional agency; coaching

\section{Introduction}

Amid the economic, managerial, technological, and societal challenges of the $21 \mathrm{st}$ century, work organizations, including those in education and health care, are increasingly expected to develop their management practices, work culture, and operations in order to provide high-quality and innovative services, including teaching and research (Billett 2011, Eteläpelto et al. 2014). At the same time, changing work practices and organizational structures impose strong demands on employees, who are 
required to develop their professional competencies and practices, cross traditional professional boundaries, re-construct professional relationships, negotiate their career, and transform their professional identity (Brown et al. 2007, Kira and Balkin 2014, Shagrir 2010, Trent 2011). For example, the pressures to engage more actively in research have challenged academics to craft their professional identity, moving from teaching towards research (Hökkä and Eteläpelto 2014, Willemse et al. 2015, Ylijoki and Ursin 2013). Similarly, in the health care context, physicians and nurses have been required to reshape their professional identities (Molleman and Rink 2015, Paloniemi and Collin 2010, Pratt et al. 2006). This is a challenge faced also by Finnish nurses, whose work responsibilities have been modified to include shift-specific leadership in addition to their everyday nursing work (Valleala et al. 2015).

Given the requirements for comprehensive professional learning that can encompass the processing of professional identities, competencies, and relationships, it is crucial that professionals should receive adequate support. If they do not have the individual resources to engage in the continuous professional learning demanded, their well-being, satisfaction, organizational performance, and commitment at work may be threatened (Brown et al. 2007, Kira et al. 2010, Vähäsantanen 2015). Moreover, amid hectic work practices, there may not always be time for learning, or for the forms of informal and formal social interaction that encourage learning (Kira 2010). The challenges to learning imply a need to foster professionals' comprehensive learning in both training and work settings.

Recent studies have emphasized that learning occurs particularly via collaboration within social interaction, plus experimentation and reflection regarding one's professional mission and practices (Labone and Long 2016, Ruohotie-Lyhty and Moate 2016, Shagrir 2010, van den Bergh et al. 2015, Zwart et al. 2015). Moreover, to 
achieve useful outcomes, social learning processes should be designed such that professionals have sufficient resources to shape their own professional identity and work (Eteläpelto et al. 2014). This touches on the notion that it is crucial to acknowledge and promote agency if meaningful learning is to be achieved (Lovett et al. 2015, Philpott and Oates 2016, Pyhältö et al. 2015, Riveros et al. 2012). In this paper, we also emphasize the importance of professional agency in learning, without ignoring the role of social context and relationships. We have thus adopted the term professional learning, since it encompasses the notion of the individual as an active participant, i.e. someone who is responsible for learning and for constructing change at a personal level within a given context (see Labone and Long 2016). By contrast, professional development would imply a more passive role for the individual.

The study reported here focused on an identity coaching programme for professionals working in Finnish education and health care. The arts-based programme included, for example, elements of sociodrama and drawings. The overall aim of the programme was to promote the participants' professional learning, notably through helping them to process their professional identities. In addition, it was aimed at supporting the participants to work with their professional roles and relationships. Professional learning was further understood as resourced by the participants' professional agency, and by the promotion of such agency. Although certain goals were defined for the programme, the participants were seen as active actors, i.e. persons whose learning was the result of their actions rather that the outcome of external forces. This implies that the actual learning outcomes of the programme might be unique and unpredictable. In the study reported here, which utilized interviews with the participants, we sought to explore the actual learning outcomes that the participants perceived as deriving from the programme. Furthermore, we wished to identify possible 
differences in the outcomes between the four professional groups that participated (academics, administrative personnel, nurses, and physicians) in order to elaborate how the programme was perceived by employees from different professions.

In this paper, we first introduce the theoretical background of the study, which builds on discussions concerning professional learning and agency. Thereafter, we present certain notions of professional learning in the context of a coaching programme. Our findings provide some practical implications for how work organizations might create meaningful identity- and agency-based learning environments for professionals.

The paper further contributes to current discussion by theorizing how professional agency and learning are intertwined.

\section{Professional learning and its support}

There are multiple ways to conceptualize professional learning and learning outcomes. Some scholars understand that professional learning includes acquiring knowledge, developing professional competencies, updating skills, and developing task performance (Dogan et al. 2016, Eraut 2011, Harteis and Goller 2014). It may also involve increased awareness of colleagues and one's own organization (Eraut 2011, Tynjälä 2013). In line with these notions, Shagrir (2014) suggests that professional learning is related to interpersonal relations (i.e. being a member of a community) as well as to building the professional self and enhancing practical skills. In the case of interpersonal relations, professional learning also refers to participation, for example, in terms of becoming an active and accountable participant who exerts an active influence on work-related matters and who undertakes initiatives for change (Toom et al. 2015, Tynjälä 2013).

According to Kelchtermans (2004), the professional learning process results from interaction with the context (both in time and space) and eventually leads to 
changes in professional practices (actions) and in the subjects' thinking about those practices. Along similar lines, Santagata and Bray (2016) understand teachers' professional learning as a process in which the teachers become aware of their own teaching practice and of alternative practices; this leads to a conceptualization of all the practices that would lead them to change and to improve their own practice. It is notable that a focus on the impact of teaching on student learning has led to an increased interest in how professional learning can support and improve teaching practice (Labone and Long 2016).

Professional learning has also been understood as a matter of crafting one's professional identity (Billett 2011, Vähäsantanen 2015). Professional identity, for its part, denotes professionals' history-based perceptions, experiences, and conceptions of themselves as professional actors. Professional identity creates a basis for professional activities and interactions (Beijaard et al. 2004, Molleman and Rink 2015), since it encompasses professionals' understanding of their current professional goals and commitments, their perceptions of what is meaningful in their work, and their future orientations as professionals (Brown et al. 2007, Davey 2013, Paloniemi and Collin 2010, Pratt et al. 2006). Here it should be noted that professional identity is not merely an individual-level phenomenon; there is also a phenomenon of collective identity, which encompasses answers to the question, 'Who are we as professionals?' (Davey 2013). Collective identity can thus be taken to refer to the mutual identification and engagement that binds individuals as a professional group; it involves the affinities they feel, and their shared professional commitments, roles, and priorities (see also Admiraal et al. 2012).

With these definitions in mind, professional learning is here understood, preeminently, as a matter of crafting professional identities. At the same time, professional 
competencies, practices, and relationships are viewed as pivotal elements in the learning of professionals. In supporting professional learning, we also assume that the focus should not be on technical and pedagogical skills and knowledge alone, since the navigation of changing professional landscapes requires social competence, in addition to the shaping of professional identities and practices (Eteläpelto et al. 2014, Lindberg and Rantatalo 2015, Shagrir 2010).

If these perspectives are taken to be valid, it is surprising that many training programmes have ignored support for the crafting of professional identities. Although some creative and collaborative tools addressing this aspect have emerged (Leicht 2010, Trent 2011), it will be crucial to find additional ways of achieving social settings within which individuals can reflect on their professional identities, and possibly create new directions for their professional lives. Arguing along somewhat similar lines, Zwart et al. (2015) emphasize the need to take teachers' qualities (including identity) as the starting point of their learning.

In this paper, we emphasize professional learning as a social process (e.g. Dogan et al. 2016) and the need to support employees' comprehensive professional learning within social settings. Social arenas are needed for the crafting of professional identities in particular, since identity is always formed and transformed through professional relationships in social contexts (Davey 2013, Ruohotie-Lyhty and Moate 2016, Trent 2011, Ylijoki and Ursin 2013). Nevertheless, we do not neglect the individual's agentic role in the learning process. In other words, we highlight the importance of professional agency for learning (see below).

\section{Professional learning and agency}

In recent years, professional agency has been one of the main concepts applied in addressing and investigating teachers' work. Agency has been seen as essential for 
teachers' collaboration, student learning, and school development (e.g. Priestley et al. 2015; Toom et al. 2015). Recent discussions have further emphasized that agency is a salient factor in the processes of professional learning - i.e. processes which include the crafting of professional practices and identities (Billett 2011, Harteis and Goller 2014, Philpott and Oates 2016, Pyhältö et al. 2015, Riveros et al. 2012). Professional agency can be understood as enacted and manifested when professional subjects or communities exert influence, act, and make decisions in ways that affect their work and professional identities (Eteläpelto et al. 2014, Toom et al. 2015). This implies that professional agency can be manifested and enacted at both individual and collective levels.

Beijaard et al. (2004) also discuss the notion of professional agency as an important element of professional identity negotiations. Agency is needed especially when there is a lack of correspondence between one's professional identity and work practices. In this case, agentic efforts can range from mere maintenance to transformation in relation to professional identity (Kira and Balkin 2014, Vähäsantanen 2015). This implies that an individual can shape his/her professional commitments and ambitions to correspond with social expectations, or else retain his/her identity on the basis of his/her experiences and professional purposes. In relation to professional identity, agentic efforts also involve planning and directing one's future pathway as a professional (Brown et al. 2007, Harteis and Goller 2014), and realizing one's preferred identity positions within the context of entire work communities (Trent 2011). According to Ruohotie-Lyhty and Moate (2016), identity-agency includes activities such as taking a new direction, developing self-confidence, judging oneself negatively, and orienting oneself towards future learning. 
The process of crafting one's identity can be challenging, since professionals need to negotiate with the possibly competing expectations that arise both from their social settings and their own professional aspirations (Beijaard et al. 2004, Pratt et al. 2006). It also appears that professional identity is resistant to change, or at least, that it may be more challenging and time-consuming to craft one's identity than one's behaviour at work (Korthagen 2004). If one's professional identity and work are misaligned, one may question existing work practices and seek to transform them to ensure that they correspond with one's identity (Kira and Balkin 2014). In this case, agentic efforts may include, for example, enriching work tasks and influencing the boundaries of the work (Harteis and Goller 2014).

To date, professional agency has been understood as involving a focus on professional identity and practices, and also - though the research on this aspect has been limited - professional relationships. Hopwood (2010) adopts a somewhat different perspective, conceptualizing agency as something that nurtures social relationships, but also as something that makes it possible to limit the scope of one's relationships and manage the degree of interaction with others. In this sense, agency in social relationships can be seen as a means of shaping the amount and intensity of contact with colleagues in different ways.

On the basis of the notions above, we see professional agency mainly as a matter of exerting influence, and of making decisions and choices regarding professional identities, practices, and relationships. Furthermore, there seem to be good reasons to view the practice of professional agency as pivotal in the learning process; it can produce different learning outcomes, including crafted professional identities, practices, and relationships. 
Here it is nevertheless important to note that the manifestations of professional agency are not always proactive and developmental; indeed, agency also includes forms of resistance towards external norms and reforms, and of maintenance of professional practices and identities (Priestley et al. 2015, Sannino 2010, Toom et al. 2015). A further matter for discussion is the temporal nature of agency. On the one hand, agency can be understood as a relatively unvarying phenomenon, insofar as structures involving stable cultural capital and social positions can strongly determine the extent of individuals' agency (Bourdie 1984). On the other hand, manifestations of agency can be viewed as changeable over time, being framed by both individual and social contributions (Archer 2003). In line with some other authors (Philpott and Oates 2016, Vähäsantanen 2015), we here incline to the latter mode of thinking, seeing manifestations of professional agency as varying from one temporal context to another.

In line with the subject-centred socio-cultural approach (Eteläpelto et al. 2014), we further see social circumstances as having the potential to both enable and constrain the enactment of professional agency, even if the agency is largely bound up with individual backgrounds (such as one's work history). In a similar manner, Priestley et al. (2015) suggest that teacher agency is not dependent on the actor, but also on the availability of the cultural, material, and structural resources that can be deployed in a given situation. Agency is therefore to be understood as emerging from the interplay of individual and environmental circumstances. According to Priestley et al. (2015) this means that any attempt to enhance agency should not focus merely on the capabilities of individuals, but should at the very same time pay attention to social relationships and conditions.

These notions regarding the affordances for agency have been supported by a number of recent studies. As Philpott and Oates (2016) have noted, professional 
learning communities are pivotal arenas, providing affordance for the enactment of agency. A longitudinal study by Sannino (2010) has also indicated ways in which resistant and disruptive activities at work may become constructive and agentive when teachers are able to work together on critical conflicts related to their teaching, within a supportive group. Furthermore, identity-agency (e.g. a form of taking a new direction for the future) can be enriched and enabled by working with individuals' personal histories within a specific group, by having one's participation recognized by other members of the group, and by having the space for success and failure (Ruohotie-Lyhty \& Moate 2016).

With these considerations in mind, it seems important to create social arenas that can support professional agency in such a way that employees are empowered to exert influence, and to make decisions relative to their professional identity, practices, and relationships. In functioning in this manner, social arenas would appear to provide the potential for comprehensive learning processes.

\section{Research questions and coaching programme}

This study investigated an identity coaching programme as a learning arena, as perceived by the participants. The following research questions were addressed:

(1) What kinds of learning outcomes were perceived by the participants?

(2) What kinds of differences in learning outcomes were identified between the professional groups that participated?

The purpose of the identity coaching programme was to promote the participants' professional learning, particularly in terms of their professional identity.

Overall, it was aimed at supporting the participants to work with (i) their professional identity, (ii) their work roles amid changes, (iii) their social roles and relations in work 
communities and organizations, and (iv) their well-being. Although these aims were assigned, the participants were also encouraged to express their wishes and hopes for the programme at the start, and to give feedback on the programme over time. The first workshop of the programme also included a discussion of the group's basic task, and generating a consensus on the ethical and functional commitments of shared working.

The purpose of the programme itself included the creation of a supportive social arena in which the participants could process and achieve a novel understanding of their identity, roles, relationships, and well-being at work, and accordingly, become strengthened to find new solutions, make decisions, and exert an influence regarding relevant work-related issues (Mahlakaarto 2014). The programme included six workshops (each lasting approximately 2.5-3 hours) over a six-month period, and it was implemented as small group coaching led by an experienced coach. Coaching is here understood as a practice providing a collective arena as well as resources and experiences (from the coach and other participants) that can help the participants to consider their own work-related experiences (and other relevant matters), and arrive at solutions and decisions regarding their work and identity (see also Kempster and IszattWhite 2012). The group-based way of working was implemented using collaborative, arts-based, creative and narrative methods, and it involved sociometry, socio-drama, pair and group discussions, drawings, and writings.

Recently, arts-based methods involving narrative inquiry (e.g. autobiographical timelines, self-system pictures, and mask making) have been advocated as means of promoting professional development and identity crafting (Leitch 2010, Taylor and Ladkin 2009). Such methods are grounded in the notion that learning does not occur solely via cognitive and knowledge-based processing and verbal expressions, and that emotions and pictorial expressions are essential for learning. Through narration, 
subjects can uncover and impart meanings about themselves and their emotions, and about the experiences in their lives (Goodson et al. 2010). In addition to group-based methods, the programme included some individual tasks relating to the themes of the programme between the workshops. As an example, Appendix 1 illustrates one method used in the programme, called the Professional Body. The method combined individual and collective processes, both of which contribute to supporting professional identity negotiations (Geijsel and Meijers 2005).

\section{Research methods}

\section{Data collection}

Altogether, 6 identity coaching programmes with 59 participants were implemented within a university and a hospital during 2012-2013. The identity coaching programme was offered to these organizations on the basis of their wish to promote the development of their personnel. Three programmes were implemented in a university with one group of administrative personnel (mostly departmental secretaries and coordinators) and two groups of academics (i.e. teachers and researchers). Three programmes were implemented in a hospital (one group of physicians and two groups of nurses). Within the groups, the participants could be employed in different work units (e.g. university departments), but they knew each other at least to some extent.

In this study, we utilized post-interviews with 49 participants. The postinterviews were conducted shortly after the end of the programme. Due to the practical problems of finding a mutually convenient time to meet, ten of the original participants could not be interviewed. Most of the interviewees were women (42) and highly educated (with 40 of the participants having at least a bachelor's degree). The average age of the interviewees was 43 years (range 27-61 years), and the average years of 
experience working in their field was 17 years (ranging from 9 months to 39 years).

Table 1 shows the participants' backgrounds by their professional groups.

Table 1. Background information on the participants $(\mathrm{N}=49)$ by professional group.

\begin{tabular}{|c|c|c|c|}
\hline Professional group & $\begin{array}{l}\text { Gender } \\
(\mathrm{F}=\text { female, } \\
M=\text { male })\end{array}$ & $\begin{array}{l}\text { Age range } \\
\text { (average) }\end{array}$ & $\begin{array}{l}\text { Range of experience } \\
\text { in the field } \\
\text { (average) }\end{array}$ \\
\hline Academics $(n=20)$ & $\mathrm{F}=17, \mathrm{M}=3$ & $\begin{array}{l}\text { 27-61 years } \\
(47 \text { years })\end{array}$ & $\begin{array}{l}9 \text { months }-39 \text { years } \\
(20 \text { years })\end{array}$ \\
\hline $\begin{array}{l}\text { Administrative } \\
\text { personnel }(n=9)\end{array}$ & $F=9$ & $\begin{array}{l}\text { 32-60 years } \\
\text { (47 years) }\end{array}$ & $\begin{array}{l}6-35 \text { years } \\
(20 \text { years })\end{array}$ \\
\hline Nurses $(n=15)$ & $\mathrm{F}=14, \mathrm{M}=1$ & $\begin{array}{l}28-59 \text { years } \\
(40 \text { years })\end{array}$ & $\begin{array}{l}\text { 3-35 years } \\
\text { (16 years) }\end{array}$ \\
\hline Physicians $(n=5)$ & $\mathrm{F}=2, \mathrm{M}=3$ & $\begin{array}{l}\text { 31-33 years } \\
\text { (32 years) }\end{array}$ & $\begin{array}{l}4-8 \text { years } \\
(6 \text { years })\end{array}$ \\
\hline
\end{tabular}

The data for the study consisted of semi-structured post-interviews. Semistructured interviews aim to gain an in-depth understanding of interviewees’ experiences and perceptions, plus the meanings that may underlie beyond individuals' actions, in line with specific themes (Kvale and Brinkmann 2009). The interviews were here conducted in such a way as to cover the following themes: (i) the current work situations of the participants, (ii) perceived learning during the programme and its outcomes and usefulness, (iii) evaluation of the contents and methods of the programme, (iv) perceptions of the individual's participation in the programme, (v) experiences of the group and the coach, and (vi) suggestions for improving the programme. An interview guide directed the interviews; this allowed the interviewer to build a conversation while at the same time focusing on predetermined themes (Kvale 
and Brinkmann 2009). However, the semi-structured nature of the interviews was such that the interviewees could convey their perceptions, experiences, and feelings openly and freely, without rigid adherence to the guidelines, or to strictly formulated questions. Note that in line with this format, no actual checklist was employed to investigate specific learning outcomes. Thus, the aim in all was to elicit fairly authentic accounts of the participants' learning. Overall, the interviews should be understood as practices in which both the interviewee and interviewer shaped the contents and course of the interview (Kvale and Brinkmann 2009).

The total duration of the interviews amounted to approximately 36 hours (averaging 50 minutes per interview). Although we utilized fairly extensive interview data from different professional groups, one limitation of the study involves the use of retrospective interviews. These do not allow for the real-time process evaluation of learning. Retrospective data collection also means that the participants can forget learning processes and outcomes and emphasize those of lesser importance in the interviews.

\section{Data analysis}

In the analysis, we intended to systematically identify the learning outcomes (i.e. expressions concerning the learning that the participants perceived during the programme) from the interviews, and to focus on potential differences and similarities in outcomes between the professional groups that participated. Within the analysis, the data were analysed via researcher triangulation in accordance with the principles of qualitative and quantitative content analyses (Cohen et al. 2007, Saldaña 2013). The aim in this analytical method is to capture the core consistencies and meanings of textual data, with a view to achieving a detailed understanding of the phenomenon under investigation. As generally employed, the process of analysis includes: coding, 
creating categories, and abstraction. In this sense, the method allows one to build a model to describe the phenomenon in a conceptual form.

As regards the first research question, the analytical process can be seen as abductive (Cohen et al. 2007). The analysis was mostly data-driven, in the sense that neither the aims of the coaching programme nor the specific theoretical categorizations directed the analysis. However, it was also partly theory-driven, since previous theoretical notions informed the process by which we identified and conceptualized the learning outcomes from the data, plus the categories to cover them.

For the purpose of the first research question, we first read the data to identify and extract the expressions indicating what the participants had learnt during the programme. We looked for expressions across different interviews and at different points in the same interview. We noticed that in many cases, the interviewees mentioned what they had learnt, but they also described how they had learnt, while at the same time mentioning the relevance of the learning to their work.

After identifying the expressions denoting what the participants had learnt during the programme, we carried out more detailed coding, category creation, and abstraction. During the coding, we read through the expressions several times and marked similar expressions about what had been learnt with the same codes. Afterwards, we listed and grouped the learning outcomes. We sorted each learning outcome into a defined sub-category according to how closely it was linked to the other outcomes in the category, as opposed to those in other sub-categories. Although each sub-category covered similar learning outcomes, there were some qualitative differences. This means, for example, that the category of crafted professional identity includes expressions of both redefining and strengthening one's professional identity. On the basis of their contents, we then grouped the sub-categories into broader 
categories (i.e. main domains illustrating professional learning). Ultimately, we identified and named four main categories, including nine sub-categories.

In addition to the above, the frequencies of learning outcomes were calculated for each sub-category and main category. The frequencies refer to the numbers of persons in each category. Thus, it should be noted that the frequencies of the main categories were not formed by adding up the frequencies of the sub-categories. For the second research question, we addressed the differences in learning outcomes among the four professional groups (academics, administrative personnel, physicians, and nurses). The frequencies (and percentages) here demonstrate the number of people from each group who reported learning outcomes in a given domain. Since the size of the professional groups varied considerably, the analysis should not be understood as an absolute group comparison. Rather, the differences between the groups can be understood as illustrating the suitability and meaningfulness of the programme for employees coming from different professions.

\section{Learning outcomes in various domains}

With regard to the first research question, the learning outcomes for the different domains are summarized in Table 2. Mostly, the learning outcomes were related to the professional self (43 out of 49 participants), professional relationships (38 participants), and professional competencies (37 participants). However, the identity coaching programme did not create an arena for purely professional learning, since 31 participants also perceived learning outcomes in the domain of personal life. The learning outcomes in the domains in question are presented in more detail in the following four sections. 
Table 2. Overview of the learning outcomes in the four domains (numbers of participants reporting the outcomes); $\mathrm{N}=49$.

\begin{tabular}{|l|l|}
\hline The professional self (43) & $\begin{array}{l}\text { Crafted professional identity (36) } \\
\text { Crystallized approach to work (26) }\end{array}$ \\
\hline Professional relationships (38) & $\begin{array}{l}\text { Increased knowledge of colleagues (30) } \\
\text { Becoming an active participant in the work community } \\
(18) \\
\text { The awakening of collective identity (18) }\end{array}$ \\
\hline Professional competencies (37) & $\begin{array}{l}\text { Advanced socio-emotional knowledge and skills at work } \\
(32) \\
\text { Improved pedagogical knowledge (15) }\end{array}$ \\
\hline Personal life (31) & $\begin{array}{l}\text { Advanced self-knowledge (25) } \\
\text { Strengthening oneself within personal relationships (14) }\end{array}$ \\
\hline
\end{tabular}

\section{The professional self}

\section{Crafted professional identity}

Several participants indicated that during the programme, they had crafted their professional identity in terms of redefining or strengthening it. Redefining their identity meant acquiring a novel or expanded understanding of their professional history and of the experiences that had shaped it. This redefinition also involved expanding and transforming their perceptions of their current professional commitments and values in their work, how to better utilize their strengths (e.g. competencies) at work, and how to progress from their weaknesses. In this sense, a redefined identity created a strong basis for professional learning and working. The quotation below illustrates how, during the programme, one participant redefined her professional identity in line with the desired researcher identity commitments. Previously, she, like many others in the group of 
academics, had struggled to find a balance between teaching and research from the viewpoint of her identity in a situation in which there were external expectations to engage increasingly in research.

During this programme, I realized that I wanted to be a researcher. Research is what I desire to do. I don't want to teach or carry out administrative duties; I want to do research. Very clearly and simply, research is my desired future profession. It is now crystal clear, and I am extremely happy in my work. In this sense, the programme has increased my professional commitment to the work.

In this sense, refining professional identity was related to positive emotions, and it created a clear direction for the professional activities.

However, some participants followed a different course, strengthening their professional identity in terms of their professional interests and their future prospects. Some participants had previously undergone an internal struggle as to whether they should transform their professional identity commitments to correspond with external pressures emerging from their work setting. During the programme, some academics, for example, found their existing professional identity as a teacher to be acceptable through sharing experiences with others; thus, they no longer felt a need to transform this identity. By contrast, for some participants, their strengthened professional identity included clearer notions of future prospects beyond the current work. In the case of one administrative person, this was based on the notion that a change in career was necessary:

Each participant was able to produce the Professional Body as they liked. I also included future perspectives in my body... I found the programme useful in that I gained strength for my identity at work. I've gained strength especially in understanding that I have to achieve some kind of change. I've become more convinced that I can't continue in the same way as I have up to now. In a sense, the programme has forced me to consider these kinds of tough new questions; 
questions that I had tried to put off till later. In a sense, I have to confess to myself that I'll have to start to look for and consider some other professional alternatives, including how I could educate myself and what else I could do for a living.

Some of the participants also made a concrete decision to start new studies, as they would be unable to express their preferred identity within their current work organization.

Overall, crafting one's professional identity seemed to be related to the participants' experiences of becoming more optimistic and enthusiastic, and more forgiving towards themselves, accepting their incompleteness, and increasing their selfesteem. Their self-esteem was strengthened, for example, via the recognition that their professional career had been successful. One academic encapsulated the perception she had gained during the programme as follows: 'I've done a good job, really, I've achieved a lot', while her previous experience had been 'I haven't really done anything, I'm so worthless'.

\section{Crystallized approaches to work}

During the programme, the participants crystallized their approaches to their work. In the first place, many participants critically reflected on their work and work-life balance. As a consequence, they adopted new approaches regarding the boundaries for the work. For example, some participants had previously worked long hours of overtime; however, during the programme, they understood that work was not the only meaningful area of their life; they thus decided to set boundaries and to limit the work done in their free time, such as answering work-related e-mails.

In some cases, the participants gained a confirmed understanding of their work performance, including the role and the quality of their ways of working. Having 
confirmation of the good and sufficient nature of one's ways of acting and thinking could further strengthen one's self-confidence at work, as one nurse reported:

Somehow I got affirmation of my own thoughts and ways of working, and of how I work as a nurse, that it's a really good and sufficient way of working... I could say that in a way I do feel that I'm more confident now, and that I've gained confirmation of my own thinking.

In contrast, some participants questioned their work practices and adopted novel ways of working. To achieve this kind of learning, it was essential to hear how other people worked and to analyse one's own work in relation to that of other people. One physician put it as follows:

The best aspect of the programme was that I heard about others' ways of working, and in that way I learnt alternative methods for coping with some work situations or with this work in particular. We don't have time here [in the hospital] to exchange thoughts in depth, and we have very little other conversation, except about the kind of patient we've had and what we did then. So, the programme offered the chance to discuss and go through one's thoughts in more depth.

Some participants also adopted more realistic perspectives on their work through realizing that they did not need to manage all the work tasks on their own, in a situation where the workload was overwhelming. The participants also developed a holistic conception of the work. For example, one administrative person noted that after the programme, she was able to focus more on what was relevant in her work (without drowning in all the details).

\section{Professional relationships}

Increased knowledge of colleagues

Many participants reported that they had increased their knowledge of their colleagues 
during the programme. The reason was that through sharing experiences about their lives and work, they had learnt about others at both the professional and personal levels. The physician quoted below found the most important outcome to be the knowledge gained about colleagues:

I got to know my colleagues better. This was the biggest benefit of the programme overall. And the most pleasant aspect, too, of why it was nice to go there, was being able to discuss these matters with these colleagues.

Such deep learning about other professionals was a new situation: according to the participants there had been no time to share knowledge in the hectic work environment. This kind of learning advanced their professional relationships. The advance in professional relationships was experienced as important for professional interaction and collaboration. The participants noted that it is easier and less stressful to work together when one knows other people's backgrounds and ways of working.

Becoming an active participant in the work community

In relation to professional relationships, some participants reported that they had adopted active ways of participating in their work community. During the programme, they considered their role within the relationships of the work community (asking themselves, for example, 'What kind of role do I have in social relations, and does this role promote my work activities?'). As a result, the participants created a novel understanding of their role in collegial relationships and made decisions on the nature of their participation in these relationships.

In the first place, the professionals became more active participants than previously, when (for example) a person might have adopted the role of a bystander. This meant that they decided to be more active and braver in influencing, taking 
stances, expressing opinions, and making suggestions in professional relationships. The next quotation demonstrates how one nurse became strengthened to have a stronger voice in the work community:

I do voice my opinions more easily now, even if I know that it won't please everybody, without being rude of course. But I do say my opinions out loud, and I don’t just go along with what others say.

Becoming an active participant in the work community also involved setting limits in relation to colleagues. For example, one academic said that she had become more strong-minded in collegial relationships. After the programme, she could say more confidently, 'No, or I won't do it, I won't come, or I'll speak to you later - I'm in the middle of doing something right now', if she was busy performing her work duties, and if a colleague wanted to discuss non-work-related matters during work hours. This was a matter of reducing unnecessary social interaction in order to work effectively. Overall, one could say that the professionals' participation was renewed in terms of being more active and assertive in collegial relationships, and in setting limits with others.

\section{The awakening of collective identity}

Some participants reported an increased sense of collective identity in their professional relationships. First of all, during the programme, when they discussed and shared experiences, togetherness increased. They further created a shared understanding of their mission and ambitions within the work organization, and their shared desires for the future. In this sense, the programme created frames for constructing a collective identity, which further improved the social climate of the work community and made it easier to collaborate. Previously, the lack of time to meet each other and to have discussions had been a serious obstacle to the construction of a collective identity. 
From strengthened togetherness and trust, the programme also created a basis for achieving a collective understanding of the meaning of, and the will for, shared activities. The participants still shared an understanding that it was useless to fight, at least alone, against some situations in the organization. However, a will for shared influence arose, with a desire to find workable ways of negotiating and acting in order to change collective matters, and to fight for a shared mission in the organization. Whereas they had previously sought to exert an influence on a purely individual basis, the participants now looked towards collective force. One academic put the matter thus:

\footnotetext{
One could think that the coaching created an opportunity to exert an influence in a new or different way, through collaboration, and through new or deepened relationships and trust. In a way, it was also about the trust being increased. We gained a lot of 'trust capital'. I do believe that in this way we can advocate and defend interests. It's sort of the only way... what's different compared to before is that up to now, the initial reaction has been a kind of passive resistance that leads nowhere, people just sulking away, 'Things are bad and we're always treated badly', and stuff like that. Now, it's more like, 'Let's go for it'.
}

As shown in the quotation, it was in particular the deepening of the professional relationships during the programme that enabled the participants to address the shared processes of influencing, taking stances, and acting within the work organization.

\section{Professional competencies}

\section{Advanced socio-emotional knowledge and skills at work}

The programme was also reported as a place for developing one's socio-emotional knowledge and skills at work. Primarily, the participants had learnt how to give and receive feedback through analysing and exercising their feedback practices in authentic professional situations. They experienced these skills as valuable in their relationships with colleagues, customers, and students. Furthermore, the programme helped the 
participants to develop their social interaction, so that they would be better at taking others into account in social relations. The participants also gained a deeper theoretical understanding of humans with different personal characteristics (e.g. narcissism). All this opened up new perspectives for understanding people and working within the social relations of the workplace, while becoming aware that social conflicts are not always one's own fault, since they are intertwined with the personal characteristics of those engaging in the interaction.

The participants also learnt to became aware of emotions at work and their importance in social relations. Furthermore, they learnt to handle their own emotions (e.g. uncertainty) at work while understanding that other participants have similar challenges at work, and to react to and approach other people and emotional work situations in more constructive, analytical, and sensitive ways, as an alternative to spontaneous emotional reactions. The emotional skills acquired made it easier to contain one's emotions without becoming nervous, or adopting the role of a martyr when one felt ill-treated at work. One nurse described how she had learnt to deal with her emotions in the work community:

[As for the benefits gained], well, we have a large work community with different personalities. We have strong and quick-tongued personalities here as nurses, and they do fire off their opinions strongly. During the programme, I gained tools for dealing with them; you don't have to go along with it or get so irritated. Maybe I didn't show my irritation before, either, but now I can actually deal with the irritation so that it won't continue to bother me, or I won't bottle it up.

\section{Improved pedagogical knowledge}

Most of the teachers and researchers reported improved pedagogical knowledge. They mentioned the usefulness of the programme in terms of making their teaching more collaborative and interactive, and learning action-based methods (e.g. tools for 
conducting drama-based exercises). The participants anticipated that they could use these methods at work, or said that they had already used them. Some of the methods might have been used previously, but an impetus was given to extend them, as one academic indicated:

I found it interesting to look at those action-based pedagogical methods and, in a sense, to recap them. I can use the methods in my own teaching; actually, I have already used them. I got this kind of concrete benefit from the programme.

The participants learnt about pedagogical competencies by observing the coach. However, the participants did not passively adopt methods; they actively considered which methods would be appropriate for them and how they could modify the methods (e.g. the Professional Body) to fit their own teaching. Some participants were further inspired to learn more about action-based methods and to develop generally as teachers. For example, they realized that they should adopt more student-centred methods.

\section{Personal life}

\section{Advanced self-knowledge}

According to the participants, the programme made it possible to gain advanced selfknowledge. Such self-knowledge was particularly related to personal strengths and how to utilize them in life, and further, to personal values, characteristics, and ways of acting, and to the participant's own personal history. Some participants gained a novel understanding of themselves as individuals. As one administrative person put it, 'The coaching has taught me to see different sides of myself that were invisible before'.

Other participants strengthened their self-knowledge, and this had the potential to increase their sense of self-acceptance. One academic reported the following: 
In a way, we learnt to know ourselves better, and features got names - the features or ways of acting that one has recognized in oneself, of being such and such a type of person and acting in a certain way. For these aspects, there were explanations and names. And all this strengthens one's sense of self and means that one can accept oneself better... that is, understanding, becoming aware, and accepting.

\section{Strengthening oneself within personal relationships}

The programme had led some participants to consider their relationships with those close to them outside the workplace. First of all, they re-defined their roles and the nature of their participation within their personal relationships. For example, during the programme, they gained the strength to create boundaries with other people, and they adopted novel ways of acting so that personal relations would be less challenging and stressful. This also meant becoming a more active participant, for example, in influencing social relationships. One academic observed that the programme had inspired her to participate more actively and exert an influence, especially in her personal life:

I think that the themes [that emerged in the discussions during the programme] regarding 'subordination, wrongful use of power, and oppression' in relationships really engendered strong feelings and a desire to solve problems at a personal level. This, in turn, has given rise to genuine agency at the level of action, both in the work community and in my personal life, relating, for example, to power relations in the children's football, where I feel I've concretely acted and influenced things in a new way, or maybe more strongly and clearly than normally.

The programme also equipped the participants with novel tools to deal with their emotions, and it developed their ability to accept critical comments in personal relations. Overall, a strengthening of personal relationships occurred through analysing and progressing through one's experiences and relationships, and also through hearing the stories of other people and obtaining their socio-emotional support. 


\section{Differences in the learning outcomes of the professional groups}

As regards the second research question, we identified some differences in learning outcomes between the professional groups that participated (Table 3). Overall, the professionals working at the university (administrative personnel, academics) perceived more value in the programme compared to the professionals working at the hospital (nurses and physicians). Another striking difference was that all the professional groups except the physicians reported learning outcomes mostly in the domain of the professional self. By contrast, the physicians mostly reported outcomes in the domains of professional relationships and competencies, and (unlike the other groups) did not mention outcomes in the personal domain at all. One could speculate that the physicians had a strongly professional, competence-based orientation towards their learning, and felt no need to reflect on their personal selves.

Table 3. Participants' $(\mathrm{N}=49)$ learning outcomes in the four different domains among the four professional groups (numbers of participants reporting the outcomes for each domain).

\begin{tabular}{|l|c|c|c|c|}
\hline & $\begin{array}{c}\text { Academics } \\
\mathbf{( 2 0 )}\end{array}$ & $\begin{array}{c}\text { Administrative } \\
\text { personnel (9) }\end{array}$ & $\begin{array}{c}\text { Nurses } \\
(\mathbf{1 5})\end{array}$ & $\begin{array}{c}\text { Physicians } \\
\mathbf{( 5 )}\end{array}$ \\
\hline $\begin{array}{l}\text { The professional self } \\
\mathbf{( 4 3 )}\end{array}$ & $19(95 \%)$ & $9(100 \%)$ & $12(80 \%)$ & $3(60 \%)$ \\
\hline $\begin{array}{l}\text { Professional } \\
\text { relationships (38) }\end{array}$ & $15(75 \%)$ & $8(89 \%)$ & $9(60 \%)$ & $5(100 \%)$ \\
\hline $\begin{array}{l}\text { Professional } \\
\text { competencies (37) }\end{array}$ & $17(85 \%)$ & $7(78 \%)$ & $8(53 \%)$ & $5(100 \%)$ \\
\hline Personal self (31) & $17(85 \%)$ & $7(78 \%)$ & $7(47 \%)$ & $0 \%$ \\
\hline
\end{tabular}


Other explanations for the differences in learning outcomes between the professional groups are worth considering. The contents of the programme might not have been entirely relevant to the needs of the hospital staff. Alternatively, the participants did not report learning in domains in which they were already strong. For example, one could surmise that the participants did not describe outcomes in professional relationships if they already had good knowledge of others. Furthermore, the perceived outcomes might have been related to the nature of the work. For example, the academics reported that they developed pedagogical knowledge and that they would be able to apply the pedagogical methods they had learnt during the programme. For the hospital staff, this was not feasible, given the nature of their work. Despite this, they learnt competencies relevant to their work, such as how to give feedback and how to deal with emotions.

Overall, despite some differences in learning outcomes between the professional groups, the programme seemed to provide a fruitful learning arena for the participants. However, it is noteworthy that six participants did not report any outcome in the domain of the professional self, even though the programme was aimed specifically at supporting the participants' professional identity crafting. In this sense, the programme did not fully achieve its aims, although these six participants reported positive learning outcomes in other domains.

\section{Discussion and conclusions}

The focus of this paper was on professional learning and agency in an identity coaching programme. In contrast to most professional learning-oriented discussions and innovations (e.g. Dogan et al. 2016, Labone and Long 2016, Santagata and Bray 2016), this programme approached professional learning and its enhancement in a fairly 
comprehensive manner, in preference to aiming at a specific, one-dimensional outcome relating to professional knowledge, skills, or practices. The findings also showed that the programme was perceived as a rich learning arena. During the programme, the professionals progressed particularly in terms of crafting their professional identity, increasing their knowledge of other professionals, becoming more active in the work community, and developing their socio-emotional skills.

The participants experienced learning outcomes relating to the professional self, relationships, and competencies as particularly important. Learning in these domains was perceived as useful for working and collaborating in professional relationships. As with the present study, previous studies (e.g. Lindberg and Rantatalo 2015) have similarly emphasized the importance of improving socio-emotional skills in current health care work. In the present study, even if the aim was not to increase pedagogical knowledge, the academics did also emphasize the importance of improved pedagogical skills and knowledge, as elements that produced changes in their practices. In line with current discussion (e.g. Labone and Long 2016), it seems reasonable to assume that the programme had an impact on the quality of teaching, and thereby on student learning.

Although advanced professional competencies were widely reported as learning outcomes, learning mainly occurred in the domain of the professional self, and particularly in relation to professional identity. It should also be noted that as compared to previous studies, which have mostly addressed and promoted professional identity crafting at the individual level (e.g. Eteläpelto et al. 2014, Ruohotie-Lyhty and Moate 2016, Trent 2011), the present study provided novel evidence that learning-oriented programmes can activate participants to develop their collective identity (including a shared understanding of their mission, with a novel understanding of shared potential ways of exerting influence). This kind of outcome can be seen as relevant in professions 
such as in education and health care, which are based on close interaction and collaboration between professionals (Admiraal et al. 2012, Davey 2013, Molleman and Rink 2015).

From the particular context of the identity coaching programme, it is possible to derive some theoretical and practical notions concerning professional agency and learning. Professional agency is conceptualized as comprising real efforts, actions, and decisions, particularly regarding professional identity and work (Toom et al. 2015, Vähäsantanen 2015). In this sense, professional agency plays a pivotal role in professional learning (Billett 2011; Harteis and Goller 2014, Riveros et al. 2012). One could say that within the social settings and relationships of the identity coaching programme, the professional agency of most participants was strengthened and activated vis-à-vis various professional domains. Overall, our findings are consistent with the view that the enactment of individual professional agency can be understood as capable of generating various learning outcomes, including transformations of one's professional identity and relationships.

With regard to professional identity, the agentic activities and decisions that took place here were related, for example, to transforming perceptions of one's professional commitments, understanding how to progress beyond professional weaknesses, and taking a new career direction. Along similar lines, a study by Ruohotie-Lyhty and Moate (2016) suggests that identity-agency can include orienting oneself towards future learning. However, in contrast with the present study, their study indicated that it can also involve a subsequent loss of confidence (Ruohotie-Lyhty and Moate 2016). In our own study, professional agency also emerged relative to professional relationships. The participants' decisions involved becoming a more active participant in collegial relationships, while at the same time being able to set limits 
regarding other professionals. In this regard, the findings are in line with the study by Hopwood (2010); in this it was shown that agency in social relations can include choices to deepen social relationships, but also to limit the degree of interaction with others.

On the basis of our findings, we emphasize the importance of acknowledging and promoting professional agency in and for learning (Eteläpelto et al. 2014, Harteis and Goller 2014, Pyhältö et al. 2015). However, one should also remember that manifestations of agency are not always proactive and development-oriented (Toom et al. 2015). It should be noted that in this study, not all the participants reported learning in the domains of the professional self, relationships, or competencies. One could surmise that the professional agency of these participants, in terms of making a change in their professional lives, was neither strengthened nor activated during the programme. Such observations, do not, however, conflict with the overall conception of professional agency as the transformative and reproductive power to achieve professional learning (Vähäsantanen 2015).

Our practical conclusions include notions of how professional learning could be promoted. In describing their learning outcomes, some participants also indicated how they had learnt within the social and arts-based frames of the programme. In line with previous studies (Geijsel and Meijers 2005, Ruohotie-Lyhty and Moate 2016, Trent 2010), the crafting of a professional identity seemed to occur via talking and sharing experiences, but also via personal reflections and gaining feedback. Here, following notions presented e.g. by Leicht (2010), we would argue that arts-based methods, such as the Professional Body, can be effective tools to support participants in processing their work-related matters and in making decisions concerning their professional identities, within the continuum of the past, present, and future. The study also indicated 
that professional perceptions expanded, and professional practices developed, through encountering different people and their perspectives, observing the coach, and evaluating one's own work experiences (see also Kira 2010, van den Bergh et al. 2015).

Altogether, the social learning arenas provided seemed to create a foundation for enhancing professional agency, in terms of making a difference in the participants' professional life. In line with Zwart et al. (2015), we would argue for the usefulness of taking the professional self - along with its core attributes, such as identity, and endeavours to process that identity - as a starting point in professional learning. We see this as a promising way of promoting changes also in one's professional practices and relationships. Following the line of argument of Philpott and Oates (2016), we would also emphasize a need to pay more attention to how to support identity shifts beyond merely changing practices, or requiring teachers to change their practices.

On the basis of the findings, we would argue that work organizations can promote employees' comprehensive and meaningful learning. We suggest, in line with current notions (Shagrir 2010, Zwart et al. 2015), that the primary emphasis of professional learning should be on the crafting of a professional identity, but also on supporting learning related to professional relationships and competencies (e.g. socioemotional skills). Arguably, this kind of learning would be facilitated if work organizations were to create adequate social settings, with opportunities to discuss and share experiences, so that professionals could be strengthened to make a difference in their professional lives. Such learning arenas should be created both in the authentic settings of work organizations and in training settings.

Although we identified some differences between the professional groups that participated in the programme, the broader picture is that in human-centred fields, such as education and health care, the promotion of professional learning should be based on 
notions of professional identity and agency. We suggest this because, despite some differences in learning outcomes, the identity coaching programme appeared overall to be a reasonably fruitful learning arena. Overall, the contribution of this study to current understandings of professional learning includes the notion that professional agency and identity are of prime importance in such learning. Nevertheless, in conjunction with the agency- and identity-oriented approach to professional learning that have presented, we would strongly advocate attention to the role of professional relationships in learning. In line with many authors we emphasize that effective learning does occur within social relationships (e.g. Dogan et al. 2016). Furthermore, as we see it, the promotion of learning processes should include processing and working with professional relationships, and with one's own role in these relationships, since this can support effective working. Here it is important to note that, as indicated by the present study, effective working could be promoted, on the one hand, by developing and deepening professional relationships (for more fluent collaboration), and on the other hand, by setting limits with colleagues. The latter course allowed better concentration on tasks in situations in which colleagues wished to address non-work-related issues.

For the most part, the identity coaching programme appeared to promote professional agency relative to individual work-related matters, but it also created the potential for awakening collective identity. However, the participants did not report that they had taken concrete actions to practise their agency collectively, either for cultivating shared work practices or for renewing the work community and organization. The broader need seems to be for learning arenas that would enhance real manifestations of collective agency for organizational learning. Indeed, we see the setting of goals and activities for both organizational and individual learning as being 
of prime importance in terms of bringing about professional learning (see also Labone and Long 2016).

The study focused on professional learning by exploring the learning outcomes during the identity coaching programme. It also gave some hints as to the characteristics of the learning processes. However, future research should seek to identify in more detail the critical conditions, processes, and specific methods that promote (or impede) learning. Previous studies have shown the need to investigate how learning is framed by the participants with their emotions and individual backgrounds, and by the learning context (Tynjälä 2013). The latter will include the feedback practices of the trainer (van den Bergh et al. 2015). Aspects of context might also link up with, for example, gender issues in professional identity negotiations and in professional agency - an aspect that was not taken up in this paper.

Although the programme appeared to have positive effects on participants' professional identities and practices, a longitudinal approach would be needed to research potential long-term outcomes and transfers to the work situation. We will also need more theoretical and empirical consideration of how collective forms of agency relate to working and learning. Finally, in line with Hopwood (2010), our findings would suggest that the conceptualization of professional agency should involve a closer focus on professional relationships, and not merely on professional identities and practices, as has been the prime focus up to now.

\section{References}

Admiraal, W., Lockhorst, W., and van der Pol, J., 2012. An expert study of a descriptive model of teacher communities. Learning environments research, 15 (3), 345361.

Archer, M.S., 2003. Structure, agency and the internal conversation. Cambridge: Cambridge University Press. 
Biesta, G.J.J. and Tedder, M., 2007. Agency and learning in the lifecourse: Towards and ecological perspective. Studies in education of adults, 39, 132-149.

Billett, S., 2011. Subjectivity, self and personal agency in learning through and for work. In: M. Malloch, L. Cairns, K. Evans, and B. O'Connor, eds. The SAGE handbook of workplace learning. London: Sage, 60-72.

Bourdieu, P., 1984. Distinction. A social critique of the judgement of taste. (Engl. Richard Nice). Cambridge: Harvard University Press.

Brown, A., Kirpal, S., and Rauner, F., eds., 2007. Identities at work. Dordrecht: Springer.

Cohen, L., Manion, L., and Morrison, K., 2007. Research methods in education. 6th ed. London: Routledge.

Davey, R., 2013. The professional identity of teacher educators: Career on the cusp? London: Routledge.

Dogan, S., Pringle, R., and Mesa, J., 2016. The impacts of professional learning communities on science teachers' knowledge, practice and student learning: A review. Professional development in education, 42 (4), 569-588.

Geijsel, F. and Meijers, F., 2005 Identity learning: The core process of educational change. Educational studies, 31 (4), 419-430.

Goodson, I.F, Biesta, G., Tedder, M., and Adair, N., 2010. Narrative learning. London: Routledge.

Eraut, M., 2011. Enhancing learning. In: M. Malloch, L. Cairns, K. Evans, and B. O'Connor, eds. The SAGE handbook of workplace learning. London: Sage, 181-197.

Eteläpelto, A., Vähäsantanen, K., Hökkä, P., and Paloniemi, S., 2014. Identity and agency in professional learning. In: S. Billett, C. Harteis, and H. Gruber, eds. International handbook of research in professional and practice-based learning. Dordrecht: Springer, 645-672.

Harteis, C. and Goller, M., 2014. New skills for new jobs: Work agency as a necessary condition for successful lifelong learning. In: S. Billett, T. Halttunen, and M. Koivisto, eds. Promoting, assessing, recognizing and certifying lifelong learning: International perspectives and practices. Dordrecht: Springer, 37-56.

Hopwood, N., 2010. A sociocultural view of doctoral students' relationships and agency. Studies in continuing education, 32 (2), 103-117. 
Hökkä, P. and Eteläpelto, A., 2014. Seeking new perspectives on the development of teacher education: A study of the Finnish context. Journal of teacher education $65,(1), 39-52$.

Kelchtermans, G., 2004. CPD for professional renewal: Moving beyond knowledge for practice. In: C. Day and J. Sachs, eds. International handbook on the continuing professional development of teachers. Maidenhead: Open University Press, 217 237.

Kempster, S. and Iszatt-White, M., 2012. Towards co-constructed coaching. Management learning, 44 (4), 319-336.

Kira, M., 2010. Routine-generating and regenerative workplace learning. Vocations and Learning, 3 (1), 71-90.

Kira, M. and Balkin, D.B., 2014. Interactions between work and identities: Thriving, withering, or redefining the self? Human resource management review, 24 (2), $131-143$.

Kira, M., Eijnatten, F.M., and Balkin, D.B., 2010. Crafting sustainable work: Development of personal resources. Journal of organizational change management, 23 (5), 616-632.

Kvale, S. and Brinkmann, S., 2009. Interviews: Learning the craft of qualitative research interviewing. Thousand Oaks, CA: Sage.

Labone, E. and Long, J., 2016. Features of effective professional learning: A case study of the implementation of a system-based professional learning model. Professional development in education, 42 (1), 54-77.

Leitch, R., 2010. Masks as self-study. Challenging and sustaining teachers' personal and professional personae in early-mid career life phases. Teachers and teaching: theory and practice, 16 (3), 329-352.

Lindberg, O. and Rantatalo, O., 2015. Competence in professional practice: A practice theory analysis of police and doctors. Human relations, 68 (4), 561-582.

Lovett, S., Dempster, N., and Flückiger, B., 2015. Personal agency in leadership learning using and Australian heuristic. Professional development in education, $41(1), 127-143$.

Mahlakaarto, S., 2014. Työidentiteetit pelissä ja peilissä - Menetelmällisiä ratkaisuja toimijuuden vahvistamiseen [Work identities at stake and in the mirrow Practical tools for supportig agency]. In: P. Hökkä et al., eds. Ammatillisen toimijuuden ja työssä oppimisen vahvistaminen - Luovia voimavaroja työhön! 
[Strengthening professional agency and learning at work - Creative resources to work!]. Jyväskylä: University of Jyväskylä, 47-65.

Molleman, E. and Rink, F., 2015. The antecedents and consequences of a strong professional identity among medical specialities. Social theory \& health, 13 (1), $46-61$.

Paloniemi, S. and Collin, K., 2010. Workplace learning and work-related identity constructions in a clinical setting. In: M. Caltone, ed. Handbook of lifelong learning developments. New York: Nova, 141-161.

Philpott, C. and Oates, C., 2016. Teacher agency and professional learning communities: What can Learning Rounds in Scotland teach us? Professional development in education, DOI: 10.1080/19415257.2016.1180316

Pratt, M.G., Rockmann, K.W., and Kaufmann, J.B., 2006. Constructing professional identity: The role of work and identity learning cycles in the customization of identity among medical residents. Academy of management journal, 49 (2), 235262.

Priestley, M., Biesta, G., and Robinson, S., 2015. Teacher agency: An ecological approach. London: Bloomsbury Academic.

Pyhältö, K., Pietarinen, J., and Soini, T., 2015. Teachers' professional agency and learning - From adaption to active modification in the teacher community. Teachers and teaching: theory and practice, 21 (7), 811-830.

Riveros, A., Newton, P., and Burgess, D., 2012. A situated account of teacher agency and learning: Critical reflections on professional learning communities. Canadian journal of education, 35 (1), 202-216.

Ruohotie-Lyhty, M. and Moate, J., 2016. Who and how? Preservice teachers as active agents developing professional identities. Teaching and teacher education, 55, $318-327$.

Saldaña, J., 2013. The coding manual for qualitative researchers. London: Sage.

Shagrir, L., 2010. Professional development of novice teacher educators: Professional self, interpersonal relations and teaching skills. Professional development in education, 36 (1-2), 45-60.

Sannino, A. 2010. Teachers' talk of experiencing: Conflict, resistance and agency. Teaching and teacher education, 26 (4), 838-844.

Santagata, R. and Bray, W., 2016. Professional development processes that promote teacher change: The case of a video-based program focused on leveraging 
students' mathematical errors. Professional development in education, 42 (4), $547-568$.

Taylor, S.S. and Ladkin, D., 2009. Understanding arts-based methods in managerial development. Academy of management learning and education, 8 (1), 55-69.

Toom, A., Pyhältö, K., and Rust, F.O.C., 2015. Teachers' professional agency in contradictory times. Teachers and teaching: theory and practice, 21 (6), 615623.

Trent, J., 2011. The professional development of teacher identities in Hong Kong: Can a short them course make a difference? Professional development in education, 37 (4), 613-632.

Tynjälä, P., 2013. Toward a 3-P model of workplace learning: A literature review. Vocations and learning, 6 (1), 11-36.

van den Bergh, L., Ros, A., and Beijaard, D., 2015. Teacher learning in the context of a continuing professional development programme. Teaching and teacher education, 47, 142-150.

Valleala, U.M., Herranen, S., Collin, K., and Paloniemi, S., 2015. Fostering learning opportunities through employee participation amid organizational change. Vocations and learning, 8 (1), 1-34.

Vähäsantanen, K., 2015. Professional agency in the stream of change: Understanding educational change and teachers' professional identities. Teaching and teacher education, 47, 1-12.

Willemse, T.M., Boei, F., and Pillen, M., 2015. Fostering teacher educators' professional development on practice-based research through communities of inquiry. Vocations and learning, 9 (1), 85-110.

Ylijoki, O-H. and Ursin, J., 2013. The construction of academic identity in the changes of Finnish higher education. Studies in higher education, 38, 1135-1149.

Zwart, R.C., Korthagen, F.A.J, and Attema-Noordewiever, S., 2015. A strength-based approach to teacher development. Professional development in education, 41 (3), 579-566. 
Appendix 1. The Professional Body as a tool for professional identity negotiation.

One method used in the identity coaching programme was the Professional Body, created by Mahlakaarto (2014). This tool combines individual and collective processes of working with one's professional identity. First of all, as a homework assignment, the participants produce a rendering of their professional body in free-form mode. The only external form is given by one's own body, whose outlines are drawn on paper. After this (still as homework), the participants can personalize their body by bringing to it (in ways of their own choosing) various themes from their professional identity, such as the following:

(1) Personality and life history: where I've come from, who I am

(2) Professional history: meaningful experiences and one's own development

(3) Skills and know-how: strengths, weaknesses, the totality of one's know-how

(4) Professional philosophy: important core principles, mission

(5) Professional development: goals, dreams, next steps, threats

These themes can be placed in the body in different ways and by various means, and a variety of materials can be used to work on and depict these, e.g. writing, painting, pictures, clippings, and drawings (see Figure1). 

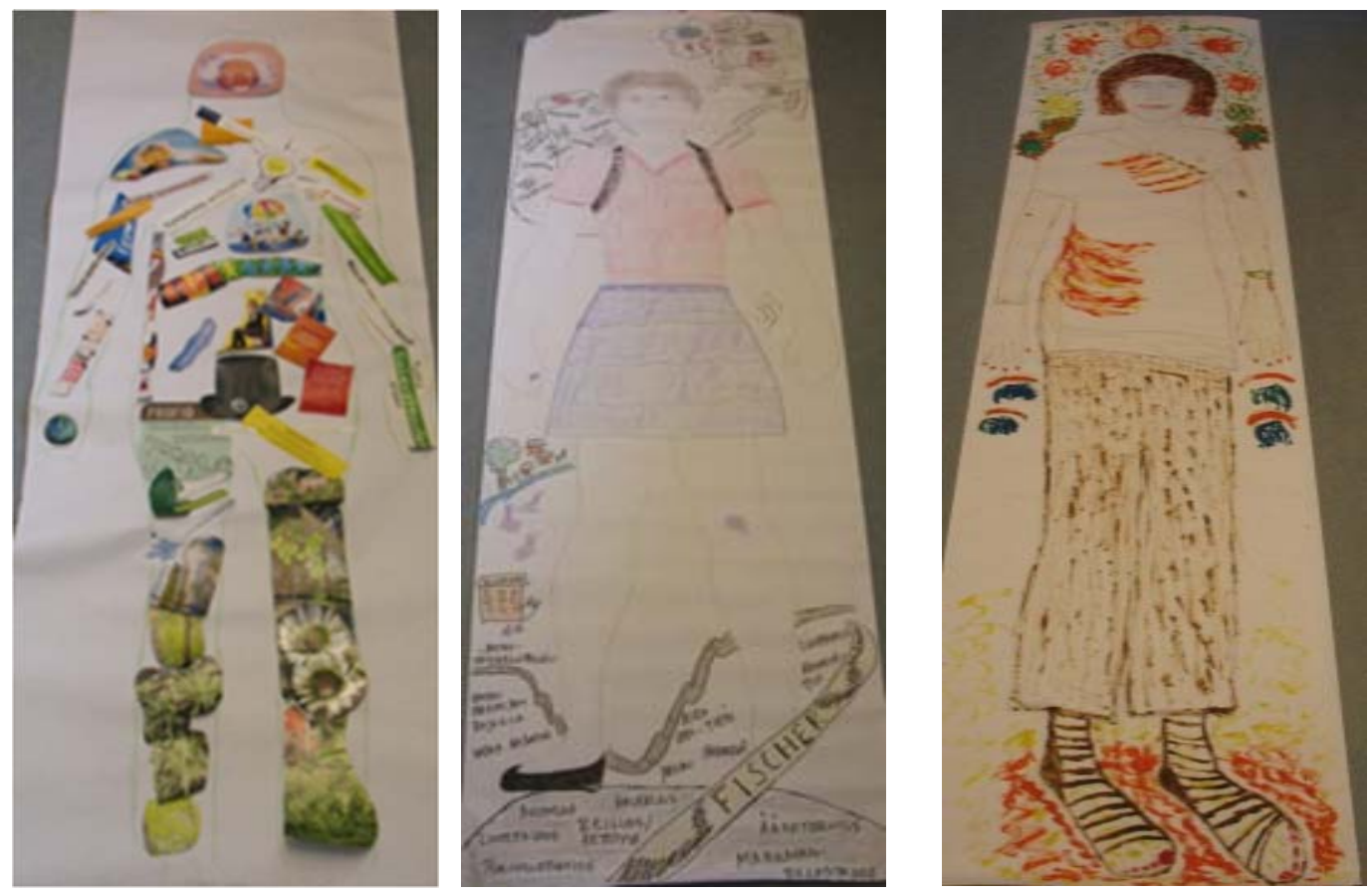

Figure 1. Examples of professional bodies.

After the individual work is done, the bodies serve as material for collective processes in a single workshop. The created bodies can be shared interactively within a group, for example, in the following way: (i) The participants get to know each other's professional bodies. (ii) Each participant stands next to the body which evokes the most interest, familiarity, strangeness, and/or amazement, and poses questions to the maker of the body, eliciting answers. (iii) Each participant presents his/her own body in more detail. (iv) The other participants comment on the body through drama, with or without words. Throughout, the coach supports the participants in negotiating each person's professional identity through empowering questions and ideas. 